\title{
Art. 11 of the Italian Constitution between text and context
}

\author{
Laura Cappuccio \\ University of Naples Federico II, Naples, Italy \\ laura.cappuccio@unina.it
}

\begin{abstract}
Luigi Bonanate's book "Costituzione italiana: articolo 11 " analyses Article 11 of the Italian Constitution through the prism of its application. Bonanate provides the reader, in a clear and compelling style, with a complete interpretation of Article 11, combining the analysis of the preparatory work in the Constituent Assembly with its doctrinal interpretation and political application. The book does not only analyse the drafting of this article, but also focuses on the "political history of Article 11", on the contemporary debate by the scientific community and, finally, on its relations with the international legal system.
\end{abstract}

\section{Keywords}

Italian Constitution - art. 11 - international agreement - war - peace

Luigi Bonanate, Italian Constitution: Article 11, Carocci Editore, Rome, 2018, 143 pages, ISBN: $978-8843088676$

Luigi Bonanate's book, Italian Constitution: Article 11, is part of the publication of a series of volumes dedicated to the reading of the fundamental principles of the Italian Constitution. These short texts are part of the various publishing events carried out for the celebrations of the seventieth anniversary of the Italian Constitution. ${ }^{1}$

1 We can recall, for example, among the other volumes of the series: URBINATI, Costituzione italiana: articolo 1, Roma, 2017; FIORAVANTI, Costituzione italiana: articolo 2, Roma, 2017; Dogliani and giorgi, Costituzione italiana: articolo 3, Roma, 2017; SAlvati, Costituzione italiana: articolo 4, Roma, 2017; STAIANO, Costituzione italiana: articolo 5, Roma, 2017. 
The first question that comes to our mind when reading Bonanate's book is why precisely the fundamental principles, why the first 12 articles of the Constitution have been the subject of this series of volumes. As recalled in the introduction to the book under review, the fundamental principles represent the face of the Republic. ${ }^{2}$ They indicate the fundamental elements of the new constitutional order. These are very general norms, which, during the preparatory work, it was decided not to place in a preamble, but rather at the beginning of the constitutional text, so as to indicate their main and fundamental features and avoid any doubt as to their effectiveness and binding nature. Mortati considered that these principles were endowed with a sort of enhanced effectiveness, of "constitutional super-legality". ${ }^{3}$ In fact, they had the function of "laying down the guidelines for the design of the subsequent parts, of providing the general criterion for interpretation, capable of bringing together in a single whole the many manifestations of the life of the State, and also marking the impassable limits to any constitutional change". ${ }^{4}$ These fundamental principles therefore express the main features of the constitutional architecture, which are also removed from the power of constitutional revision. The Corte Costituzionale, in fact, in its judgement number 1146 of 1988 stated that the Italian Constitution contains some supreme principles that cannot be subverted or modified in their essential content not even by laws of constitutional revision or other constitutional laws. These principles are not only those which the Constitution itself explicitly indicates as absolute limits to the power of constitutional revision (think of the republican form under Article 139 of the Constitution), but also the principles that "belong to

2 Costa and SAlvati, La serie "Costituzione italiana. I principi fondamentali", Roma.

3 mortati, Costituzione dello Stato, II, La costituzione italiana, in Enc. dir., vol. XI, Milano, 1962, p. $214 \mathrm{ff}$ states: "The desire to consider these principles not only as supplementary parts of the Constitution but to place them at the basis of the others, giving them direct and immediate regulatory efficacy with respect to both the legislator and any other entity, and indeed enhanced efficacy, of 'constitutional super-legality', is made clear by the rejection of the proposal, which had been formulated, to transfer them to a 'preamble' precisely in order to eliminate the possibility of doubts as to the character to be attributed to them, similar to those that have arisen in the past in France concerning Declarations of Rights formulated in documents separate from those of the Constitution" ("La volontà di considerare tali principi non solo quali parti integrative della costituzione ma di porli a base delle altre, conferendo loro diretta ed immediata efficacia normativa nei confronti sia del legislatore sia di ogni altro soggetto, ed anzi efficacia potenziata, di «superlegalità costituzionale», è resa palese dal rigetto della proposta, che pure era stata formulata, di trasferirli in un «preambolo», proprio nell'intento di eliminare la possibilità di dubbi sul carattere da attribuire loro, analoghi a quelli sorti in passato in Francia a proposito delle Dichiarazioni dei diritti formulate in documenti distinti da quelli della costituzione").

4 MORTATI, cit. supra note 3, p. $214 \mathrm{ff}$. 
the essence of the supreme values on which the Italian Constitution is based". ${ }^{5}$ According to the case law of the Corte Costituzionale, these limits also apply to the international activity of the State, which may not go against the fundamental principles and inalienable rights of the individual. ${ }^{6}$

In recent years, the issue of the relevance of the Constitution and the need for its revision has been at the centre of debate among constitutionalists, who have expressed their views on the various projects to reform our fundamental Charter. These reform projects have placed at the centre of the political agenda, public debate and scholarly debate the issue of the relevance of the constitutional text and its ability to respond to the challenges of the present day. During those same years, the celebrations were being prepared for the 7oth anniversary of our Constitution and discussions were under way for its adaptation to current times. In this context, the fundamental principles represent what remains outside the debate on reform, what cannot be changed, what expresses the hard core of our Constitution. And yet, even though formally, the fundamental principles cannot be subject to constitutional revision, this book poses a further question: can their concrete application supersede them and make them obsolete?

In this perspective, the book under review has the merit of analysing Article 11 through the prism of its application. Bonanate, in fact, provides the reader, in a clear and compelling style, with a complete interpretation of Article 11, which combines the analysis of the preparatory work in the Constituent Assembly with its interpretation by doctrine and application by politics. The first Chapter of the book is dedicated to the analysis of the drafting of this article; the chapters that follow focus on the "political history of Article 11", on the contemporary debate that has developed in the scientific community and, finally, on relations with the international legal system. ${ }^{7}$ The history of this

5 Recently, for example, with the sentence number 118 of 2015, on the law of the Veneto Region relating to the holding of a consultative referendum on the independence of Veneto, the Corte Costituzionale again reiterated the presence of these limits, recalling that "the unity of the Republic is one of those elements so essential to constitutional law as to not fall under the power of constitutional revision" ("l'unità della Repubblica è uno di quegli elementi così essenziali dell'ordinamento costituzionale da essere sottratti persino al potere di revisione costituzionale"). As this matter teaches us, fundamental principles must be constantly defended and their centrality and cogency must always be reaffirmed.

6 See, for example, inter alia, Corte Costituzionale, 18 December 1973, no. 183.

7 With regard to this last aspect, it must be recalled that Art. 11 is also interpreted within the complex international system of which Italy is part: the United Nations Organisation, the NATO, the European Union. This articulated system is investigated by the Author recalling the two different readings - monist and dualist - of the relationship between national law and international law. 
Article has been a troubled one, sometimes characterised by avoidance and disregard. ${ }^{8}$ The analysis of Article 11 cannot therefore fail to take into account how it was put into practice and how it withstood the challenges posed by history. In this perspective, Bonanate's book, which deals with how Article 11 was formulated and has been interpreted and applied, provides the reader with the necessary tools for an exhaustive knowledge of the problems that agitate the "life lived"9 of this Article in the seventy years of the Republican Constitution.

\section{$2 \quad$ An Ambitious Article}

As mentioned in Chapter one, the book reconstructs how the text was drawn up in the Constituent Assembly. This Article was discussed, by the First Subcommittee, initially through the work of Giuseppe Dossetti. Originally, the content of the current Article 11 was included in two different articles, Article 4 and Article 5, which declared, the former, Italy's membership of the international community and, the latter, the renunciation of war. In the Report on the draft Constitution of the Republic, presented by Meuccio Ruini on 6 February $1947,{ }^{10}$ we find the essential elements of the future Article 11 already indicated: the rejection of war and the choice of access to forms of limitation of national sovereignty. This Article thus expressed the desire to mark a profound difference from the Fascist era, expressing a "will to break with and oppose" the nationalist past. ${ }^{11}$ Bonanate dwells on the wording of Article 11 because he believes that in the way it was written the fundamental coordinates for its interpretation can already be found. In particular, he underlines how the text which was finally approved showed two "minimal, but significant" novelties: ${ }^{12}$ The first concerns the decision to place, after the proclamation of the rejection of war, a semicolon followed by the statement which permits the limitations of sovereignty necessary to enable participation in international organisations that ensure peace

8 For a comment to this article see also, CARTABia and Chieffi, "Articolo 11", in BifUCo, Celotto and olivetti (eds.), Commentario alla Costituzione, Torino, 2006, p. $263 \mathrm{ff.}$

9 Bonanate, Costituzione italiana: art. 11, Roma, 2018, p. 38.

10 Cfr. Bonanate, cit. supra note 9, p. 20.

11 CARlassare, "L'art. 11 nella visione dei costituenti", in www.costituzionalismo.it, 2013, p. 5. According to BENVENUTI, "La prima proposizione dell'art. 11 della costituzione italiana tra (in)attualità e (in)attuazione. Un principio decostituzionalizzato o da ricostituzionalizzare?” La comunità internazionale, 2013, p. 261 ff., p. 263, this Article expresses "an absolute novelty with respect to the militarist, warlike and colonialist past" ("un'assoluta novità rispetto al passato militarista, bellicista e colonialista"). 
and justice among nations; the second concerns the insertion, after a further semicolon, of a favour towards international organisations. Article 11 thus consists of a single paragraph made up of several statements separated by a punctuation mark. Bonanate reminds us that the very structure of Article 11 makes it possible to acquire the rules that must inspire Italian international policy. In particular, the choice of a single paragraph, with sentences separated only by a semicolon ${ }^{13}$ is seen as the expression of a fundamental choice: "in essence, article 11 states that in order to have the (moral) strength to repudiate war, a state must accept a reduction of its sovereignty and (more importantly) work towards an equally peaceful international order [...] for all states". ${ }^{14}$ Article 11 thus expresses a link between politics and war, showing the guidelines that politics must follow if it really wants to repudiate war. ${ }^{15}$

In fact, as well as recalling the long dispute between just and unjust wars - just and acceptable the war of defence/unjust and prohibited the war of aggression - the book also uses a different perspective, represented by the "primacy of politics": "no war exists which does not derive from politics; no international dispute exists that cannot be resolved politically".16 In this context, the "second half"17 of Article 11 is important because it indicates how the repudiation of war can be made realistic: the limitations of sovereignty are what will make possible the construction of a more peaceful world. We could well agree with Carlassare that the second part of Article 11 is "functional to the first". ${ }^{18}$ Thus, the idea of sovereignty as absolute, unconditional power (superiorem non recognoscens) is surpassed in favour of a limited idea of sovereignty which serves as a compass for future international relations. Our Constitution

13 The semicolon is in fact used to "separate two or more coordinated propositions from one another": see Punto e virgola in Enciclopedia Treccani, https://www.treccani.it/enciclopedia/ punto-e-virgola_(La-grammatica-italiana) BONANATE, cit. supra note 9, p. 24.

15 As BonANATE, cit. supra note 9, p. 27, the term repudiate was chosen because it implies both "condemnation and renunciation of war" (COSSIRI, "Art. 11", in BARTOLE and BIN (eds.) Commentario breve alla Costituzione, Padova, 2008, p. 10 highlights the "almost unanimous convergence (with only two votes against) of the Constituents in the «repudiation» of the War" (la "convergenza quasi unanime (con due soli voti contrari) dei Costituenti nel «ripudio» della Guerra"). In this analysis of the text, Bonanate emphasises how the repudiation of war does not rivet an absolute value being anchored by the provision to conflicts as an instrument of offence and resolution of international controversies. It is not by chance that the book recalls the first monograph dedicated to this article, in which it is stressed that it was a "vigorous condemnation of the war to which recourse is made in some cases", see вON VALSASSina, Il ripudio della guerra nella Costituzione Italiana, Padova, 1955, p. 3 о quoted by BONANATE, cit. supra note 9, p. 28

16 BONANATE, cit. supra note 9, p. 33 .

17 Ibid.

18 CARLASSARE, cit. supra note 11, p. 9. 
therefore simultaneously turns its back on the past and imagines a new world in which international relations can avert war. An ambitious ${ }^{19}$ and far-sighted Constitution. If we analyse the debate on sovereignty today, we realise that sovereignty is always accompanied by something else: we talk about the crisis of sovereignty, the overcoming of sovereignty, the decline of sovereignty. ${ }^{20} \mathrm{In}$ this formulation of Article 11 emerges the great topicality of the constitutional text, which, through a limited vision of sovereignty, imagined the construction of a new world of international relations. ${ }^{21}$

\section{3}

\section{Article 11: Between Interpretation and Application}

After this reconstruction of the meaning of Article 11, the author accompanies the reader in the analysis of the events that have taken place over time. He starts from the first period, from 1948 to 1989 , when the world was divided into two blocs, each with its own military force: the NATO and the Warsaw Pact. The author focuses precisely on Article 5 of the NATO, which states that an armed attack against one of its members will be considered as a direct attack against all the parties, and consequently member states will assist the attacked party or parties by "taking immediately, individually and in concert with the other parties, such action as is deemed necessary, including the use of armed force, to restore and maintain security". The book shows how the tensions between this Article and Article 11 are immediately evident and will return in the different readings put forward in doctrine on the lawfulness of military operations in which our country should be involved. It is no chance occurrence that in the debate on the scope of Article 11, we see a return of the question, already present in the discussions following the approval of the constitutional text (think of the positions expressed by Perassi in 1952 and Bon Valsassina in 1955), on the efficacy of the fundamental principles: does this article have legal value or does it express only a programmatic orientation? In other words, can Article 11 bind politics? Does the rejection of war express a political-ideological option, or can legal consequences also be drawn from it? This question is the backdrop to the various events examined by Bonanate, which show how, on many occasions, article 11 is

19 CASsese, Lo Stato e la Comunità internazionale, in BRAnCA (ed.) Commentario della Costituzione, Bologna-Roma, 1975, p. $461 \mathrm{ff}$.

20 BONANATE, cit. supra note 9, p.36, underlines the "innovative importance of this formula", which "has a greater intrinsic value than the repudiation of war itself".

21 It should be noted that one part of the text also deals with the phenomenon of European integration, which had "at its ideal and moral centre the abolition of war between all its 
read in the light of "realistic" considerations, which hinge on the participation of our Country in international organisations that provide military protection. ${ }^{22}$

In particular, after 1989, the end of the division of the world into blocs presented new challenges. The author emphasises the different extent, for example, of Italian participation in the war in Kuwait. In fact, while the foreign policy negotiations of the 1950s had in some cases even been concluded secretly, ${ }^{23}$ with the war in Kuwait, Article 11 is "explicitly adapted by the government and the majority that supported it to its own intentions". ${ }^{24}$ With the doctrine of the so-called humanitarian war, then, we witness a reversal of Article 11: the limitations of sovereignty which are at the basis of Italy's participation in international organisations can surpass the limit expressed by the constitutional text. The overturning, therefore, of the meaning of Article 11: limitations of sovereignty are no longer the instrument to overcome wars, but to legitimise them. The fundamental principle of the repudiation of war is thus circumvented by the international agreements entered into by Italy, which involve the country in military missions abroad. The operation of counter-limits to the international openness of the State, i.e. the presence of supreme principles of our constitutional order that act as limits to the implementation of international agreements, is superseded by the priority given to Italy's membership of international organizations. ${ }^{25}$

In the case of Italy's participation in the war in Kosovo, the book reminds how the doctrine proposed different interpretations of Article 11, which put the accent on its being superseded (an obsolete constitutional norm, which is not able to respond to new conflicts) or on its inclusive capacity (a norm that is able to include this war, through the commitments that Italy has undertaken in the international context). ${ }^{26}$ Bonanate also recalls the position expressed by the then President of the Council of Ministers, who admitted humanitarian

members". The book recalls how even today the Treaty on European Union states in the first paragraph of article 3 that the Union shall aim to promote peace, its values and the wellbeing of its peoples; and in the fifth paragraph, that the Union shall contribute to peace, security, the sustainable development of the Earth, solidarity and mutual respect among peoples. BONANATE, cit. supra note 9, p.59.

23 Ibid., p. 47 recalls the case of the Bilateral Infrastructure Agreement, signed in 1954 relating to the concession of military bases and their organisation and management, never presented for ratification to the Italian parliament, pursuant to Art. 80 of the constitution.

24 BONANATE, cit. supra note 9, p. 62.

25 Ibid., p. 67.

26 BARTOLE, Interpretazioni e trasformazioni della costituzione repubblicana, Bologna, 2004, p. 13, departs precisely from the Italian participation in the war in Kosovo, to indicate an "interpretation of the Constitution which is not easily traceable to a literal reading thereof, 
conflict through a reading of the two parts of Article 11, according to which "respect for limitations on sovereignty would make it possible to overcome the principle of repudiation of war". ${ }^{27}$ The successive wars on terrorism (Enduring Freedom, Coalition of the Willing) have also shown various cases of circumvention of the constitutional provisions. Within this context, the book analyses the different ways of looking at Article 11 (which underline the fact that it has been superseded, the need for a reading in step with the times, or reaffirm its full operativity ${ }^{28}$ ) not as the expression of a dispute over doctrine, but as tools for reading the procedure followed by our country. While, in fact, Article 11 expresses a clear indication of foreign policy, the procedure described has shown its violation, leaving the reader "a bit amazed and a bit bitter". ${ }^{29}$ The questions about the capacity of Article 11 to guide policy (emblematic in the case of the challenges posed by the so-called new wars) constantly return. So, what future awaits Article 11? The author raises the question of possible solutions: to reaffirm its importance, the need to observe it, or to consider it "fallen into disuse"?30

The reader is thus confronted with the reconstruction of a constitutional fundamental principle that has suffered the most from the impact of history and its developments (as it emerges from the discussions on its deconstitutionalization). This book provides orientation to understand the scope and the main interpretations of Article 11 in a context where war and its meaning have changed. Even if the book highlights the critical issues arising from its application, Article 11 continues to express a "manifestation of great and admirable juridical civilisation", which we must strive towards, like a compass indicating the path towards the "formulation of a constitution of international relations" which "is the great project we must work on". ${ }^{1}$

because it is enriched by external elements, that is, from the developments taking place in international law [...]" ("interpretazione della Costituzione non agevolmente riconducibile alla lettera di questa poiché arricchita da elementi ricavati aliunde, cioè dagli svolgimenti in atto nel diritto internazionale $[\ldots] "$ ).

27 BONANATE, cit. supra note 9, p. 66.

28 These different interpretations of Art. 11 are represented in the text through the work of three authors (De Verogottini, Ronzitti, Carlassare) whose positions are often recalled to analyse the historical development of Art. 11.

29 BONANATE, cit. supra note 9, p. 121.

$30 \quad$ Ibid., p. 125.

$31 \quad$ Ibid., pp. 126-127. 